\title{
Title: Trace of Islamic Educational Thought
}

Pontianak: STAIN Pontianak Press

By: Erwin Mahrus and Syamsul Kurniawan

Reviewed By

Farninda Aditya

(Pontianak State Institute of Islamic Studies)

Don't judge a book by its cover, goes the popular saying. It is probably true as the cover does not always represent the contents of the book. However, this one is an exception. Without looking at the title, one will immediately think of: the important figures in Islamic education.

The book that traces the thought of Islamic education figures such as Ibnu Sina, Al-Ghazali, Ibn Khaldun, Muhammad Abduh, Hasan Al-Banna, Syed Muhammad Naquib Al-Atlas, Muhammad Iqbal, K.H. Ahmad Dahlan, K.H Hasyim Asy'ari, Azyumardi Azra in pictures displayed in a golden frame on the cover of the book. The contents of the book focus on one important thing: the thought of Islamic education. In addition to the figures shown on the cover, $\mathrm{H}$ asan Langgulung and Imran Basiuni are also discussed.

The book that introduces the thought of Islamic education from various periods not only discusses the figures from other Islamic countries and Indonesia, it also explores the thoughts of those born in West Kalimantan. Basiuni Imran who was born in Sambas and studied in Mecca and Egypt had an important role for Islamic education of West Kalimantan.

Dominant in green, this book does not directly present the thoughts of the figures to the reader. The first part begins with the biography of each notable. These figures can inspire the readers. Both authors of this book are lecturers at IAIN Pontianak. Through this works, they introduced the characters the students. In addition to serving as an Islamic education reference, it also may become life inspiration for the students.

The thought of the figures shown in the book should be introduced to the students especially those who major in Islamic education. Students as the younger generation can learn more about the development of Islamic education from time to time. The purpose of writing of this book is "to elaborate and explain the concept of education put forward by educational professionals among Muslims».

According to the authors, the thought of Islamic educators is important as it may serve as a basis for consideration in policy decisions in accordanc 
e with the conditions in order to restructure the Islamic educational system, particularly in Indonesia. By reading the introduction, it is clear that the figures shown in this book are the reliable references. In total, 158 references were used to write the 316 page book. Erwin Mahrus who currently is a lecturer of Islamic education studies once wrote a biography of Basuni Imran, and Syamsul Basuni Kurniawan has a master's degree in Islamic studies in the field of Islamic educational thought.

This book is divided into 16 chapters. In the early chapters the authors first discusses the study of Islamic education in general. The first chapter is dedicated to the thought of Islamic education in Indonesia in which the authors explained the notion of Islamic thought, the purpose of the study, and the principles of Islamic educational thought. The second chapter is about the periods of Islamic education before and after independence to show that different were struggles carried out so that the community under any circumstances should get education.

The next chapter is about the Islamic education in the early days. The development of Islamic education thought during the time of the Prophet, Khulafa Al-Rasyidin, Umayya, and Abbasiya. After a discussion of the study of Islamic educational thought in general in chapter four, the author laid out the ideas of Islamic education proposed by the figures in chapter four and the next twelve chapters.

In each chapter, it is not merely a discussion of the Islamic educational thought leaders in general or its conclusion. The biography of those figures is also an interesting topic. The authors also deliver important factors in education based on the thoughts of the figures. In fact, every chapter is not only focused on finding an explanation of the purpose of education, curriculum, teaching methods, the concept of a teacher, the duties and responsibilities of students, evaluation, the concept of punishment in the teaching, etc, but the authors also stressed on the significance of Islamic educational thought to restructure education in Indonesia.

From the description of the educational thoughts, one can learn about the development of thought in Islamic education. AR-Ruzz Media as the publisher of the book said "... the advancement of civilization of a nation will be determined by how education is carried out by its people." To advance the civilization of the community, Islamic education proponents continue to make educational innovations. This is evident from modern educational institutions initiated by Imran Basiuni in 1936. The development of a more modern education can be seen from the thought of Islamic education put forward by Azyumardi Azra who, according to the author, is a contemporary think- 
er that paid attention to the 'Islamization' of knowledge. On the last page of the last chapter in this book, the thought of Azyumardi Azra concludes the development of education. "His thought has relevance to the development of science and technology, even in his works he strived to anticipate the future so he ought to be placed into the modernist group. 